This item was submitted to Loughborough's Research Repository by the author.

Items in Figshare are protected by copyright, with all rights reserved, unless otherwise indicated.

\title{
In touch: textiles and communication
}

PLEASE CITE THE PUBLISHED VERSION

http://www.routledge.com/9780367252441

\section{PUBLISHER}

Routledge

VERSION

AM (Accepted Manuscript)

PUBLISHER STATEMENT

This is an Accepted Manuscript of a book chapter published by Routledge in Textiles, Identity and Innovation: In Touch on 10 June 2020, available online: http://www.routledge.com/9780367252441.

\section{LICENCE}

CC BY-NC-ND 4.0

\section{REPOSITORY RECORD}

Barnard, Malcolm. 2020. "In Touch: Textiles and Communication”. Loughborough University. https://hdl.handle.net/2134/12497807.v1. 
Barnard, M. (2020) "In Touch: Textiles and Communication", in Montagna, G. and Carvalho, C. (eds) Textiles, Identity and Innovation: In Touch, London, Routledge (ISBN 9780367252441)

In Touch: Textiles and Communication

Malcolm Barnard

Loughborough University

One of the meanings or senses of 'in touch' in English is 'in communication'. We talk of being 'in touch' with someone, meaning that we know them and that we are in communication with them. We also speak of being 'out of touch' with someone, meaning that we are not in contact with them, that we are not communicating with them. And we talk of being 'put in touch' with someone: this usually means that a third party has made contact or established communications on our behalf, between us and someone else. Sometimes, sadly, we talk of 'losing touch' with someone, meaning that we were in contact with someone, maybe through Christmas cards or WhatsApp but are no longer in communication with them..

Other languages also make or perform this metaphorical shift. According to Google Translate, touch translates as contato in Portuguese. And Portuguese also makes this metaphorical slide from touch to being in touch, in contact and thus in communication with someone. Google Translate tells me that 'Entrar em contato' means to get in touch with someone. Touch is slightly different in French but one of the translations of touch in French is also contact and 'en contact avec' means to be in communication with someone in French. The metaphorical drift from in touch, being in touch, through contact to communication is common to many languages. We might say that touch translates into communication, or it communicates by

keeping in touch, with in or through various languages. And I'd like to think about this conceptual and textual contact in the present paper.

Famously, the other translations of touch in French are le toucher and la touche and I will be touching on, talking and writing a little more about, Derrida's investigations of these words later.

First, I'd like to think a little bit more about the sense of communication and its conceptual connections to culture, and then the relation to textiles and clothing. From the world of cultural studies, Colin Cherry says 'a group of people, a society, a culture, I would define as "people in communication"' (Cherry 1957: 4). This is interesting Cherry defines a culture in terms of a group of people who are in communication with each other, who are in touch with each other.

In a lot of cultural studies, the standard model or explanation of this being in touch and this communication is the sender/receiver model. This model or understanding really is as simple as it sounds: a sender sends a message through a channel and that message is received by a receiver. There is usually a complication, in the form of noise, added to this model. Noise is defined as anything received by the receiver 
that was not sent by the sender. It may not need pointing out but it may help to know that this model of communication originated in telephonic engineering around the middle of the twentieth century. The technology and the problems accompanying that technology have driven the conceptual apparatus and the explanations it is able to give ever since.

Textiles and clothing are said to be means or modes of communication and they are commonly or routinely understood and explained in terms of this sender/receiver model. People happily and thoughtlessly say we send messages with the textiles we use and the clothes we wear. People also happily and thoughtlessly say that we express ourselves through what we wear. These phrases are commonplace in everyday speech, in journalism and even. I'm sad to say, in academic journals and university departments.

This Roz Chast cartoon, for example, illustrates the sender/receiver model of communication and it shows how clothing and textiles are thought to send messages on this model. Rhonda Perlmutter III's stripy skirt sends the message that 'mother lives in Sacramento, but we speak quite often on the telephone'. Her bow sends the message that Rhonda doesn't like to dust. The idea is that Rhonda, or the garments, (and here is a clue to some of the deficiencies of the model) send messages. These messages are sent through the channel of the garments or the textiles. And they are received by the receivers.

Chast is clearly having a lot of fun lampooning the sender/receiver model of communication and satirizing the idea that textiles and clothes send messages in this way. As I hinted, the model has many deficiencies. One is that it is not clear who or what the sender is: is it Rhonda or is it, as the image suggests, the garments? Might it not also and equally plausibly be the textiles designer, or the fashion designer? Similarly, it is not clear who is the receiver. Is it Rhonda? Is it us? Is it the person or the fashion company who commissioned the design? And finally there is the problem of noise. In order to identify noise, one would have to know what was and what was not sent by the sender, in order to tell the difference between it and whatever was received by the receiver. This assumes that the sender is in full and total control of the message and has a complete and unchanging understanding of the message which they can document and record once and for all. However, the world is full of supposed senders who either do not know what the message is, or was, or who change their minds about the nature or content of the message. Given this manifest lack of control and possible absence of or change in understanding, noise does not and cannot exist.

However, apart from anything else and more importantly for us, this model assumes that there is a self that exists before the expression or the sending of the messages, before the being in touch and before the communication. Simply, on this model, Rhonda exists and then sends messages using textiles and clothing. I would like to argue that this is not what happens and that textiles have a much more complex and a much more significant role than that of the channel through which preexisting subjects and selves and cultures send messages about themselves. 
From the world of French philosophy, Jean-Luc Nancy offers a slightly different but not incompatible perspective from that of Cherry and Chast. He argues that 'Being in touch is what makes us "us"' (Nancy Being Singular Plural p. 13, quoted in Derrida On Touching p. 115). This is an argument about the conditions for the possibility for there being either a singular or a plural us. Either an 'us' as a single self or subject or an 'us' as a group or culture. Nancy has the condition the other way round from the sender/receiver model and his argument is more in line with Chast's critique of this model.

It is not that there is a subject or a self, let alone an 'us', that then sends messages, communicates or expresses itself through some exterior material or textile. Rather the exterior material or textile makes the self and the us possible: the supposedly exterior material or textile is the condition for there being a subject or self. The being in touch, the representation in and through some exterior thing or text/ile is the condition for there being an 'us' or a we. This is what Nancy means when he says that being in touch makes us 'us' - the representation through the exterior material makes a self or an 'us' possible 'in the first place'.

However, the point is also that touch is not direct or unmediated - between toucher and touched, my hand and an object, my hand and an other person or even my own hand and my own other hand, there is always a mediation, some material, some prosthesis between toucher and touched (Hillis Miller 2009: 297). As Derrida has it in On Touching, we have to get away or dissociate ourselves from the common sense or the philosophical sense of touch as immediacy (Derrida 2005: 119). Some prosthetic, some technical object, some art or artifice always comes between us and the thing or the person we think or believe ourselves to be in touch with, to be in contact or communication with.

Firstly, as Hillis Miller argues, 'Words, marks of some kind, always come between touching-touched and touching-touched' (Hillis Miller 2009: 297). As far as language is concerned, Hillis Miller's point is that, for 'us' to even have the experience of touching/being touched, and for us to be said to be having any experience or perception at all, it is necessary that that experience or perception be 'presented' or represented to ourselves and the only way we have of doing that is through the use of language, using concepts as the form and content of words.

Secondly, 'some form of materiality, like a sort of intervening skin or membrane, always comes between the two touchers and touched, even when I touch myself' (Hillis Miller 2009: 2978). Another word for this materiality, this intervening skin or membrane, would be textiles. Language, and textiles, are different forms or different ways of identifying and describing the thing, the prosthesis, that is not us and which comes between us as touchingtouched or us as perceiving-perceived and makes the experience or the perception possible.

At the same moment, in the same movement, this prosthetic at once makes possible and destroys experience- even the experience of ourselves as selves - most importantly for this conference, even our sense of ourselves as an I or an us. This 'in touch' (this textile) both makes possible and destroys, or more 
accurately mediates and delays, our experience of ourselves as an I and as an us. Even to have a sense, a knowledge or an experience of ourselves as selves or as subjects, some exterior thing (language, most importantly, but also text in the sense of a textile) is necessary. We have no direct or immediate contact with or intuition of our selves or of ourselves as subjects: we are not even in touch with ourselves in any direct or immediate way - some external thing, such as language or I want to argue textile, makes contact and therefore us possible.

Ultimately this impossibility of being in touch with ourselves in any immediate, or unmediated way, without some external thing (what I will explain as the prosthesis) both making that contact possible and deferring or complicating and delaying it, is the product of the work of Edmund Husserl. Husserl's phenomenology is based on the idea of a simple and unmediated present instant or moment but is actually undermined from within by the idea that what we experience and understand as the immediate and punctual present instant is complicated by past retentions and future protentions.

Past retentions are basically memories and future protentions are basically anticipations or expectations concerning the future. Both are representations of things that are not simply or fully present but which are the conditions for our experience of a full and simple present. Therefore, there is no direct experience of the simple present or of our simple selves in that simple present - it is always represented in something that is not us, in something exterior to us. Derrida argues that this exterior thing is text, or writing. It is some exterior and material thing that is not us. To give a hint of where I am going with this, or more accurately where I am trying to follow Derrida with this - the exterior material thing that is not us but which makes us possible through communication is the prosthetic, the technical - textiles, for example.

This exterior materiality that Derrida calls writing or the trace and that Hillis Miller mentions is usually language but as Hillis Miller also mentions it is also a membrane, a sort of intervening skin. It is thus a textile, and it is also what we wear: it is also clothing and fashion. The link between text and textiles is not fortuitous and Derrida makes much of it at various places in his work. The link to style in and of Derrida's work, and thus to fashion in the work of textiles, is also not fortuitous and Derrida makes much of this as well.

One of the consequences of these arguments is that textiles and thus clothing and fashion are not messages to or from pre-existing subjects, selves or cultural groups: textiles and clothing are also by no means direct means or modes of communication. On this argument, in order for us to be a subject, or an us, or a 'we' as Nancy has it, we have to represent ourselves, our self or our subjectivity, to ourselves - and we can only do that though some external thing language/text.

For Derrida and Nancy, it also means that the material, the text or the textile does not follow the toucher/touched: both toucher and touched, even when I touch myself, always follow or are made possible by the materiality, the text or textile. As I suggested Nancy 
reverses the direction of the condition so that being in touch, being in communication by means of textiles, is the condition of there being an us, of there being a self or a subject or a culture.

This something that follows or is secondary is also mentioned by Hillis Miller when he mentions the prosthesis (Hillis Miller 2009: 297). Therefore, this argument, this reversal of the direction of the condition, also means that we must adjust or in some cases abandon our notion of textiles and clothing as substitutive or supplementary prosthesis. They are both often, too often, thought of as substitutive prostheses - as something that stands in for or supplements something else that already exists but is deficient or lacking in some way

This is the sense of prosthesis that the Roz Chast cartoon depends upon for its humour and which it satirizes - the items of clothing are prostheses in the sense that they represent, stand in or substitute for what Rhonda means and thus who she is. The textiles and the garments are believed to send messages about her, they are not her but they stand for her and her messages. This is the routine or everyday sense of textiles and clothing that they send messages about us somehow coming after us, they represent or stand in for us.

However, on the constitutive prosthesis account of textiles and clothing, the items make her and her messages possible; the textiles and the materiality make her and her meanings possible. They are the condition for her, for her identity and thus her sense of self. In this new(ish) account of textiles as prosthesis, there is no substitution - in this sense the textiles make the thing possible in the first place

This is Derrida's concept of the constitutive prosthesis, which he works on in his (2010) Copy, Archive,

Signature. Derrida explains that the constitutive prosthesis makes experience, even perception, possible. As he says, 'there is no perception before the possibility of prosthetic iterability' (Derrida 2010: 14).

Derrida's argument is that it is not that there is experience or perception and then something like a textile or a garment (or a word) communicates that experience and perception. Rather the textile, the materiality, the thing that is not us and that is therefore a prosthetic, makes that experience and perception possible (Derrida 2010: 1314). This argument uses or represents a whole new sense of the idea that we are in touch through textiles and what we wear. This is the sense in which we are, we only come to be, to exist because of textiles, because of what we wear. On this account, textiles and fashions as constitutive prostheses are the conditions of our existence, not the consequences of it.

This is the paradox of the constitutive prosthesis - it is a prosthesis, it is an exterior thing and it is an addition, but it makes the thing to which it is exterior and to which it is an addition possible in the first place. Thus there is no subject until the subject represents itself (even to itself) in or though the exterior materiality of

language/text/textile. One consequence of this argument is that we do not express ourselves through textiles or what we wear. Not only are Rhonda's clothes and hat not sending messages, they are also not expressing her interior thoughts or feelings. For us to express ourselves in or through what we wear, there has to be something 
inside that is pressed or forced out, that is what express means.

There also has to be a subject, a self or some content that we take to be a self in order for it to be ex-pressed. The point of the constitutive prosthesis is that there is no I, no self and no 'content' until it has been represented in something that is not it and that exists outside and apart from it - the prosthesis or textile. It also means that we do not send messages with what we wear, or that our clothes send messages about us. Roz Chast's critique of the sender/receiver model is accurate and should be fatal; it is an absurd model of communication and I wonder how we keep using it.

There is no 'we' and there is no 'us' until the meaning of the textile has been constructed by whoever is looking at us, or touching us, including us as we touch ourselves (Derrida 2005). This is the meaning of Nancy's argument that being in touch makes us 'us'. It is not that there is an us, either an individual or a collective us, and then we get in touch via textiles and fashion. The 'in touch' of the textiles and the fashion make us an 'us', 'in the first place'. The problem indicated by the scare-quotes is, clearly, that there is and can be no first place, just as there can be no messages sent or received.

Finally, this argument concerning the understanding of textiles as the or a constitutive prothesis is consistent with a very odd thing that Thomas Carlyle says in Sartor Resartus. In this book, he declares that 'society ... is founded on cloth' (Carlyle 1987: 48). I have noted elsewhere (Barnard 2002: 49) that this is an astonishing thing to suggest and I don't know anyone who takes him up or makes issue with him on this point. I suspect that commentators think this is either a provocative or throwaway comment from someone who has form in this area, or that it can be safely ignored.

Actually, this idea of the constitutive prosthesis is a both condition for and a development of what Carlyle says in Sartor Resartus. In order to understand Carlyle's idea of society being founded on cloth, we have first to make sense of the idea of the textile or fashionable prosthesis being a condition for, not a consequence of, our various identifications. By identifications I mean the ways in which we construct ourselves - our class, social, cultural, sexual, gender and national identifications, for example. This is the idea of the constitutive prosthesis.

The condition for his being able to say what he says is the constitutive prosthesis. Carlyle is correct to say that cloth, or textiles, make society possible so long as we conceive of cloth or textiles as constitutive prosthesis. As Cherry points out, 'a society ... a culture, I would define as "people in communication"' (Cherry 1957: 4). Communication may be explained as the condition for there being a society or a culture. Following Nancy, I have argued that textiles, as 'in touch' and as communication are the condition for 'us' being an 'us'. If we take the 'us' to be a society or a culture, then textiles or cloth are what makes society possible, just as Carlyle says. And one of the consequences is that subjectivity and thus intersubjectivity, identity, society and culture, are made possible by the constitutive prosthetic that is textiles.

And it is a development of what Carlyle says in that Carlyle never goes this far; he never identifies the condition for his being able to say that society is founded on cloth. He is more 
interested at this point in presenting the outrageous pronouncements of Professor Teufelsdröckh than in the conditions or consequences of those pronouncements. However, we are interested and we can investigate and suggest some of the conditions and consequences. It is not that we are, that we exist, or that we have an individual or cultural identity or meaning and then we get dressed, or then we use textiles and fashion: the textiles and the fashions are the condition for the possibility of us being an individual, an us or a we and they start the process of identification 'in the first place'.

For all these reasons, textiles is much more important than even textile designers think and being or keeping in touch is the condition of our existence, not something that may befall us or happen by chance.

Bibliography

Barnard, M. 2002 Fashion as Communication, London, Routledge

Carlyle, T. 1987 Sartor Resartus, Oxford, OUP

Cherry, C. 1957 On Human Communication, Mass., MIT Press

Derrida, J. 2005 On Touching - Jean-Luc Nancy, Stanford, Stanford UP

Derrida, J. 2010 Copy, Archive, Signature, Stanford, Stanford UP

Hillis Miller, J. 2009 For Derrida, New York, Fordham UP 